\title{
Intravenous fentanyl PCA during labour
}

Eeva M. Nikkola MD, ${ }^{*}$ Ulla U. Ekblad $M D,{ }^{\dagger}$ Pentti O. Kero MD, ${ }^{\ddagger}$ Jukka J.M. Alihanka MD, Markku A.O. Salonen MD*

Purpose: To evaluate the usefulness of intravenous patient-controlled analgesia (PCA) fentanyl for labour analgesia, its effectiveness for matemal pain and safety for the fetus and newbom.

Methods: Twenty primigravidas were randomised to receive intravenous PCA fentanyl or epidural analgesia for labour pain. Maternal pain, heart rate and arterial oxyhaemoglobin saturation $\left(\mathrm{SpO}_{2}\right)$ were monitored. Fetal and neonatal monitoring induded cardiotocogram (CTG), APGAR, neurological scoring and static-charge-sensitive bed (SCSB) recording for $12 \mathrm{hr}$ postnatally with $\mathrm{ECG}$ and $\mathrm{SpO}_{2}$. Fentanyl concentrations and $\mathrm{pH}$ of umbilical artery and vein were analysed.

Results: Initially, epidural analgesia was more effective $(P=0.01)$, and three patients in the fentanyl group were given epidural due to unsatisfactory pain relief. Overall satisfaction for analgesia did not differ between the groups. Maternal side-effects were more frequent in the fentanyl group (dizziness and tiredness most often, $P=0.000 \mathrm{I}$ ). Severe sideeffects were not reported. In CTG there were no differences between groups. All the newborns were healthy, APGAR and pH were normal. Naloxone was not used. Neurological scoring was similar in both groups. In $12 \mathrm{hr}$ monitoring heart rate, breathing frequency and movement time were similar in both groups, but $\mathrm{SpO}_{2}$ was lower in the fentanyl group $(P<0.001)$. Umbilical cord fentanyl concentrations were low or beyond the detection limit.

Conclusion: Intravenous fentanyl can be used for labour analgesia with the doses reported here as an alternative to epidural analgesia. However, the fetus and neonate must be appropriately monitored. Naloxone and oxygen should be available if neonatal distress occurs.

Objectif : Évaluer l'importance de l'analgésie intraveineuse auto-contrôlée (PCA) au fentanyl en analgésie obstétricale en tenant compte de son efficacité et de la sécurité foeto-matemelle.

Méthodes : Vingt primipares ont été assignées aléatoirement à recevoir soit du fentanyl intraveineux en PCA soit une analgésie épidurale dans le but de soulager la douleur de l'accouchement. La douleur maternelle, la fréquence cardiaque et la saturation artérielle $\left(\mathrm{SpO}_{2}\right)$ ont été notées. Le monitorage foetal et néonatal incluait la cardiotocographie (CTG), le score d'APGAR, l'évaluation neurologique et l'enregistrement au lit sensible à la statique (SCSB) pendant $12 \mathrm{~h}$ après la naissance avec l'ÉCG ET la SpO ${ }_{2}$. La concentration de fentanyl et le $\mathrm{pH}$ de l'artère et de la veine ombilicales étaient mesurés.

Résultats : Initialement, l'analgésie épidurale s'est avérée plus efficace $(P=0,01)$ et trois patientes du groupe fentanyl ont dô accepter une analgésie épidurale à cause du manque de soulagement. La satisfaction globale en rapport avec l'analgésie n'a pas différé entre les groupes. Des effets maternels secondaires sans gravité sont survenus plus souvent dans le groupe fentanyl (surtout des étourdissements et de la fatigue, $P=0,000 \mathrm{I}$ ). Le CTG n'a pas révélé de différences intergroupes. Tous les enfants sont nés en bon état avec des scores d'APGAR et des $\mathrm{pH}$ normaux. On n'a pas administré de naloxone. L'évaluation neurologique était identique dans les deux groupes. Après $12 \mathrm{~h}$ de monitorage de la frequence cardiaque, la fréquence respiratoire et le temps de mouvement étaient identiques dans les deux groupes mais la $\mathrm{SpO}_{2}$ était plus basse dans le groupe fentanyl $(P<0,00 \mathrm{I})$. Les concentrations ombilicales de fentanyl étaient faibles ou impossible à déceler.

Conclusion : Pour l'analgésie de l'accouchement, on peut substituer le fentanyl intraveineux selon les doses utilisées à l'analgésie épidurale. Cependant, le foetus et le nouveau-né doivent être surveillés de près. Il faut avoir du naloxone ou de l'oxygène à portée de main pour traiter la détresse néonatale potentielle.

From the Departments of Anesthesiology, ${ }^{*}$ Obstetrics and Gynecology, ${ }^{\dagger}$ Pediatrics ${ }^{\ddagger}$ and Physiology ${ }^{5}$ Turku University Hospital, Kiinamyllynkatu 4 - 8, 20520 Turku, Finiand.

Address corraspondence to: Markku Salonen MD; Phone: $+358-2-2611611$; Fax: $+358-2-2613960$

Supported by funds from Instrumentarium Research Foundation, Finland and funds from Turku University Hospital, Finland. Accepted for publication September 10, 1997. 
$\mathrm{E}$ PIDURAL blockade is known to be effective and safe in labour pain treatment. There are, however, situations when it is contraindicated, for example infections or bleeding disorders. In many hospitals anaesthesia services and epidural blockade are not available $24 \mathrm{hr}$ a day. Also, it has been suggested that epidural blockade in labour is associated with increased maternal intrapartum fever and neonatal sepsis requiring antibiotic treatment. ${ }^{1}$ Therefore, alternatives for labour analgesia are needed.

Parenteral medication offers an option for these situations. In a survey of 17 European countries im meperidine was the most common method of providing labour analgesia. ${ }^{2}$ Yet, the effectiveness of meperidine is limited, ${ }^{3}$ and it is associated with many harmful fetal and neonatal effects. ${ }^{4-12}$ Morphine has also been used in labour analgesia, but the results are poor. It has very limited analgesic effects and causes maternal sedation. ${ }^{13}$

Of the other opioids, fentanyl has some qualities that make it a promising candidate for obstetric use. It has a rapid onset and short duration of action, ${ }^{14}$ and it lacks active metabolites. ${ }^{15}$ The elimination half-life in normal neonates varies between 75 and 440 min. ${ }^{16}$ Fentanyl has proved to be suitable for neonatal anaesthesia. ${ }^{17}$ Possible harmful effects can easily be reversed with naloxone. ${ }^{18}$

Fentanyl has also been used in labour. It has no adverse effects on uterine tone or blood flow. ${ }^{19}$ When given by hourly in injections of 50-100 $\mathrm{gg}$ for labour analgesia there was no increase in the incidence of respiratory depression or low APGAR scores. Furthermore, neonatal neurological and adaptive capacities at 2 and $24 \mathrm{hr}$ after delivery were normal. ${ }^{20}$ Only a brief decrease in fetal heart rate variability was reported. In a randomised comparison of fentanyl and meperidine for labour analgesia, the need for naloxone was less after fentanyl, although there were no differences in neurobehaviour at 2 and $24 \mathrm{hr}$ postpartum. ${ }^{21}$ The authors concluded that fentanyl was preferable to meperidine.

Intravenous fentanyl PCA has been used in obstetrics. ${ }^{22,23}$ The advantages of PCA method include a lower dose of opioids, and that mother has control over her pain management. ${ }^{24}$ Randomised studies on PCA fentanyl in labour have not been published.

The purpose of this retrospective, randomised study was to evaluate the usefulness of iv PCA fentanyl for labour pain in a small number of mothers. The efficacy of fentanyl for maternal pain relief and its safety for the fetus and newborn were assessed.

\section{Materials and methods}

After local committee approval and written informed consent, 20 healthy primigravidas were studied when they arrived at the hospital in labour. Inclusion criteria were age 20-35 yr and weight $<100 \mathrm{~kg}$ before pregnan- cy. Exclusion criteria were complications of pregnancy, regular use of drugs or chronic diseases.

When the mothers asked for pain relief, they were randomised to receive either iv fentanyl $(\mathrm{n}=10)$ or epidural block $(n=10)$. In the fentanyl group a loading dose of $50 \mu \mathrm{g}$ fentanyl was initially injected. Then, a patient-controlled pump (Graseby 3300) was set to deliver bolus doses of $20 \mu \mathrm{g}$ fentanyl with a lock-out period of five minutes. The maximum dose in one hour was $240 \mu \mathrm{g}$. If the $i v$ fentanyl was ineffective, epidural analgesia was offered. Bupivacaine $0.5 \%$ was used in the epidural group. Initially, $6 \mathrm{ml}$ were injected between $\mathrm{T}_{12}-\mathrm{L}_{1}$. On request, additional $4 \mathrm{ml}$ doses were given via the epidural catheter. ${ }^{25}$ For safety reasons, in this initial study, we did not treat pain in the second stage of labour with $i v$ fentanyl. In our hospital epidural analgesia is also not routinely given in the second stage.

Maternal heart rate and arterial oxyhaemoglobin saturation $\left(\mathrm{SpO}_{2}\right)$ were continuously monitored with the oximeter attached to a finger (Datex Satlite). Pain relief was rated every 30 min by the patient using a $100 \mathrm{~mm}$ long ungraded visual analog scale (VAS). Side-effects (sedation, nausea, vomiting, respiratory depression, other) were registered with a four graded scale (none, mild, moderate, severe).

In addition to routine monitoring, fetal cardiotocogram (CTG) was monitored twice, for $30 \mathrm{~min}$, using a computerised system for antenatal fetal heart rate analysis (System $8000^{26}$ ). It was recorded before and one hour after pain relief was started. In addition, the CTG signals were visually analysed by two independent obstetricians, who were not familiar with any clinical data of the patients.

Umbilical artery and vein blood samples were drawn immediately after delivery for plasma fentanyl determinations. Each sample was centrifuged and stored at $-20^{\circ} \mathrm{C}$ until the time of assay. The samples were assayed in duplicate by radio immunoassay technique using commercially available kits (Diagnostic Products Corporation, Los Angeles, USA). The sensitivity of the assay was 0.08 $\mathrm{ng} \cdot \mathrm{ml}^{-1}$, the intra-assay variability was $<4 \%$ and the interassay variability $<7 \%$. Umbilical artery and vein $\mathrm{pH}$ values were also analysed.

APGAR scores at $I, 5$ and 15 min were assessed by delivery room personnel. At the age of one hour each infant had a neurological capacity scoring ${ }^{27}$ performed by one of the authors (EN). Passive and active tone, primary reflexes and general assessment were scored (maximum 30).

From the age of one hour the babies rested for $12 \mathrm{hr}$ on the static-charge-sensitive bed (SCSB) (Biomat, Biorec Inc., Turku, Finland). The SCSB consists of a mattress-like movement sensor placed in a normal bed. It has three static-charge lavers. The original movement 
signal is preamplified and filtered into three separate signals. These three signals are body movements, respiratory movements and ballistocardiogram. The SCSB method is noninvasive, and it allows continuous and long-term monitoring of the neonate. ${ }^{28}$

Together with SCSB monitoring, ECG and $\mathrm{SpO}_{2}$ were continuously measured for $12 \mathrm{hr}$. The oximeter (Ohmeda Biox 3700e) probe was attached around the foot of the baby. The recordings took place on a newborn ward, in a normal nursery room. The SCSB recordings were stored on diskettes and printed and blindly scored afterwards by one of the authors (EN), using software developed for the SCSB recordings (BRIl, Biorec Inc., Turku, Finland). The different sleep stages (awake, active sleep, intermediate sleep and quiet sleep) were scored according to criteria published by Alihanka. ${ }^{29}$

The neurological capacity scoring was repeated at the end of the recording, i.e., at approximately $13 \mathrm{hr}$.

The day after delivery, mothers were asked about the overall effectiveness of their pain relief, using a scale poor, moderate, good and excellent. Mothers who had received both in fentanyl and epidural analgesia gave their opinion of each separately.

Statistical calculations were done using the Minitabstatistical software (Release 10, State College, PA, USA). Student's $t$ test was used for normally distributed data. Pain data were analysed using a two-way repeated measures analysis of variance. Oxygen saturation distributions as well as dichotomic subjective assessments were calculated using a Chi squared test. A $P$ value of 0.05 was considered statistically significant.

Assuming a clinically significant decrease in breathing frequency (primary endpoint variable) from 25 to 22 and a SD of 2 the power of our analysis should be $90 \%$ with a group size of 10 .

\section{Results}

Maternal weight at labour did not differ between groups. At the time of randomisation oxytocin had not been used and all the mothers were in active labour, cervical dilatation $3.7 \pm 0.6 \mathrm{~cm}$ in the fentanyl group and $4.1 \pm 1.6 \mathrm{~cm}$ in the epidural group (mean $\pm S D$ ). Supplemental oxygen was not used during labour.

In the PCA group the dose of fentanyl varied between 190 and $885 \mu \mathrm{g}(447 \pm 202 \mu \mathrm{g})$. Mean hourly doses are presented in Figure 1. Three of the ten patients in the fentanyl group were given epidural blockade because of unsatisfactory pain relief, and one because we suspected that fentanyl was prolonging the labour. The duration of fentanyl analgesia was 43 to 418 $\min (153 \pm 102 \mathrm{~min})$, and the mean time between the last dose of fentanyl and delivery was $92 \pm 81 \mathrm{~min}$ (including those with epidural blockade after intra-

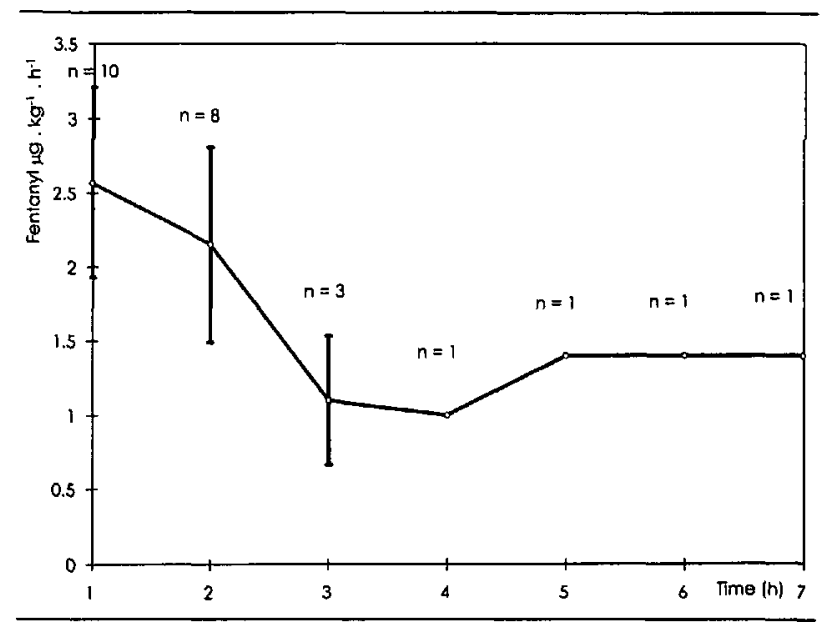

FIGURE 1 Mean hourly dose of fentanyl $( \pm S D)$. N = number of patients still receiving fentanyl at each time.

venous fentanyl). In the epidural group, five mothers received one epidural top-up and one mother had two top-ups (at cervical dilatation 6-9 cm). Mothers who received both $i v$ fentanyl and epidural analgesia did not require epidural top-ups. Demands from the PCApump are summarised in Table I.

Maternal heart rate was regular and $\mathrm{SpO}_{2}$ was $295 \%$ in every subject throughout labour and delivery. Subjective opinions about the pain relief are presented in Table II. The VAS for maternal pain up to one hour resulted in a time $x$ treatment interaction $(P=0.01)$ : initially, epidural blockade was more effective than fentanyl PCA. The overall effectiveness of fentanyl PCA and epidural blockade did not differ between groups.

TABLE I Demands from PCA-fentanyl-pump

\begin{tabular}{llll}
\hline $\begin{array}{l}\text { during } \\
\text { bour }\end{array}$ & $n$ & $\begin{array}{l}\text { total demands } \\
\text { median (range) }\end{array}$ & $\begin{array}{l}\text { good demands } \\
\text { median (range) }\end{array}$ \\
\hline 1 & 10 & $23(3-74)$ & $8.5(3-11)$ \\
2 & 8 & $24.5(5-103)$ & $9(4-11)$ \\
3 & 8 & $7.5(2-35)$ & $3.5(1-6)$ \\
4 & 2 & $6.5(3-10)$ & $3(1-5)$ \\
5 & 1 & 9 & 7 \\
6 & 1 & 11 & 7 \\
7 & 1 & 9 & 7 \\
\hline
\end{tabular}

TABLE II Effectiveness of pain relief, subjective opinions

\begin{tabular}{lcc}
\hline & \multicolumn{2}{c}{ No of patients } \\
\hline & Fentanyl & Epidural \\
Excellent & 1 & 1 \\
Good & 5 & 7 \\
Moderate & 2 & 2 \\
Poor & 2 & 0 \\
\hline
\end{tabular}


TABLE III Maternal side-effects

\begin{tabular}{llll}
\hline & \multicolumn{3}{c}{ No of patients } \\
\hline Feeling cold & Fentanyl & Epidural & $P$ \\
Shivering & 0 & 2 & NS \\
Nausea & 0 & 2 & NS \\
Vomiting & 3 & 1 & NS \\
Numbness of feet & 2 & 0 & NS \\
Dizzyness & 0 & 1 & NS \\
Tiredness & 6 & 0 & 0.0001 \\
Difficulty in breathing & 0 & 0 & 0.0001 \\
\hline
\end{tabular}

Fentanyl group mothers had more side-effects than epidural group mothers (Table III). Tiredness and dizziness were the most common and all side-effects were mild or moderate. One mother in the fentanyl group and four in the epidural group had no side-effects.

There were no differences in overall variability of CTG between the two groups either before pain relief or one hour later. The overall variability before pain relief was $39.1 \pm 6.9 \mathrm{msec}$ in the fentanyl group and $44.5 \pm$ $11.8 \mathrm{msec}$ in the epidural group (normal $>30 \mathrm{msec}$ ). One hour after pain relief the values were $43.4 \pm 12.1$ and $45.1 \pm 20.6 \mathrm{msec}$, respectively. In the visual analysis of CTG no drug related changes were seen either.

Fentanyl was detectable in umbilical blood in five of the ten newborns. Concentrations varied between 0.10 and $0.66 \mathrm{ng} \cdot \mathrm{ml}^{-1}$. Arterial concentrations were $0.10 \pm 0.21 \mathrm{ng} \cdot \mathrm{ml}^{-1}$ and venous $0.13 \pm 0.20 \mathrm{ng} \cdot \mathrm{ml}^{-1}$.

The data on the delivery outcomes are presented in Table IV. The indications for instrumental delivery were either prolonged second stage of labour or suspected fetal asphyxia. All babies were healthy at birth: none was asphyxiated or needed intensive care. Naloxone was not used. The APGAR scores, umbilical blood $\mathrm{pH}$ values and the results of Amiel-Tison's neurological capacity scoring did not differ either at the age of one or $13 \mathrm{hr}$.

In the fentanyl group, babies demonstrated more active sleep and less quiet and intermediate sleep and

TABLE IV Data on the deliveries and babies

\begin{tabular}{|c|c|c|c|c|c|c|c|c|c|}
\hline \multirow[b]{2}{*}{ Patient } & \multirow{2}{*}{$\begin{array}{l}\text { Pain } \\
\text { relief }\end{array}$} & \multirow{2}{*}{$\begin{array}{l}\text { Labour duration } \\
\text { after initial } \\
\text { pain relief } \\
\text { (min) }\end{array}$} & \multirow[b]{2}{*}{ Delivery } & \multirow{2}{*}{$\begin{array}{l}\text { Birth weight } \\
(G)\end{array}$} & \multirow[t]{2}{*}{ Apgar } & \multicolumn{2}{|c|}{ Umbilical blood $p H$} & \multicolumn{2}{|c|}{ Nezurological scoring (max 30$)$} \\
\hline & & & & & & Artery & Vein & $1 H$ & $13 H$ \\
\hline 2 & Fentanyl & 85 & Normal & 3790 & $9,9,9$ & 7.45 & 7.45 & 26 & 27 \\
\hline 3 & Fentanyl & 215 & Normal & 3800 & $9,9,9$ & 7.16 & 7.22 & 25 & 25 \\
\hline 6 & Fentanyl + Epi & 265 & Normal & 3470 & $9,10,10$ & 7.29 & 7.33 & 28 & 27 \\
\hline 7 & Fentanyl & 150 & Normal & 3450 & $8,8,8$ & - & 7.29 & 24 & 27 \\
\hline 8 & Fentanyl + Epi & 175 & Normal & 3860 & $9,9,9$ & 7.13 & 7.31 & 27 & 28 \\
\hline 11 & Fentanyl + Epi & 300 & Normal & 3860 & $8,9,9$ & 7.18 & 7.35 & 25 & 27 \\
\hline 12 & Fentanyl & 160 & Normal & 2960 & $9,9,9$ & 7.27 & 7.44 & 27 & 26 \\
\hline 15 & Fentanyl & 480 & Normal & 3750 & $9,9,10$ & 7.20 & 7.34 & 25 & 26 \\
\hline 18 & Fentanyl + Epi & 450 & Normal & 3140 & $9,9,9$ & 7.13 & 7.22 & 25 & 25 \\
\hline \multirow[t]{3}{*}{19} & Fentanyl & 175 & Normal & 3610 & $8,9,9$ & - & 7.37 & 24 & 28 \\
\hline & Mean & 245.5 & & 3569 & & 7.23 & 7.33 & 25.6 & 26.6 \\
\hline & $\mathrm{SD}$ & 130.5 & & 313.6 & & 0.11 & 0.08 & 1.3 & 1.1 \\
\hline 1 & Epi & 265 & Forceps & 3870 & $9,9,9$ & 7.18 & 7.34 & 22 & 27 \\
\hline 4 & Epi & 275 & Normal & 3450 & $7,8,8$ & 7.21 & 7.27 & 26 & 27 \\
\hline 5 & Epi & 125 & Normal & 3330 & $9,9,9$ & 7.27 & 7.40 & 28 & 29 \\
\hline 9 & Epi & 305 & Normal & 4000 & $9,9,9$ & 7.18 & 7.25 & 25 & 27 \\
\hline 10 & Epi & 190 & Normal & 3100 & $9,9,9$ & 7.31 & 7.40 & 24 & 25 \\
\hline 13 & Epi & 185 & Normal & 3740 & $9,8,8$ & 7.26 & 7.39 & 22 & 24 \\
\hline 14 & Epi & 165 & Vacuum ex. & 3380 & $8,9,9$ & 7.30 & 7.32 & 27 & 28 \\
\hline 16 & Epi & 360 & Normal & 4250 & $10,10,10$ & 7.33 & 7.33 & 25 & 25 \\
\hline 17 & Epi & 120 & Vacuum ex. & 3340 & $9,9,9$ & 7.19 & 7.28 & 25 & 28 \\
\hline \multirow[t]{4}{*}{20} & Epi & 360 & Vacuum ex. & 3600 & $9,9,9$ & 7.17 & 7.30 & 25 & 27 \\
\hline & Mean & 235.0 & & 3606 & & 7.24 & 7.33 & 24.9 & 26.7 \\
\hline & $\mathrm{SD}$ & 90.3 & & 355.3 & & 0.06 & 0.05 & 1.9 & 1.6 \\
\hline & $P$ & NS & & NS & & NS & NS & NS & NS \\
\hline
\end{tabular}

Epi = Epidural blockade, Vacuum ex. = Vacuum extraction, $\mathrm{SD}=$ Standard deviation, NS = Non-significant. 
fewer awake periods than did the epidural group, but the differences were not statistically significant.

Heart rate in the fentanyl group newborns was 120 $\pm 7 \mathrm{bpm}$ and $120 \pm 8 \mathrm{bpm}$ in the epidural group during the whole recording. The same values for breathing frequency were $25 \pm 3$ and $25 \pm 2$ per min. During different sleep stages there were no differences between groups. No time-dependent trends were seen in heart rate, breathing frequency or in the amplitude of breathing. The movement time in the fentanyl group babies was $7 \pm 5 \%$ and in the epidural group babies $7 \pm 3 \%$ of the recording time.

The minimum and the maximum oxygen saturation values were lower in the fentanyl group infants $\left(P<0.001\right.$, Figure 2), and the occurrence of $\mathrm{SpO}_{2}$ $<90 \%$ was more numerous in the fentanyl group $(P<0.05)$. Episodes of desaturation $<80 \%$ were rare and similar in frequency in both groups. None of the babies received oxygen supply during the monitoring period.

Babies whose mothers received only $i v$ fentanyl did not differ from those who had received both fentanyl and epidural for pain relief. Neonatal variables did not correlate with the total fentanyl dose or with the interval between the last fentanyl dose and delivery. Also, epidural blockade is unlikely to cause neonatal effects similar to opioids. Therefore, mothers and babies who received both fentanyl and epidural were analysed in the fentanyl group.

\section{Discussion}

In this randomised study we evaluated the effectiveness and safety of $i p$ fentanyl PCA for labour analgesia compared with epidural block. Epidural analgesia proved to be superior in effectiveness. Nevertheless, more than half of the patients in the fentanyl group were comfortable with PCA fentanyl, which suggest that fentanyl has some potential in relieving labour pain. In neonates we did not find any serious opioid-related effects, but $\mathrm{SpO}_{2}$ was lower in the fentanyl group of babies during 12 hours monitoring.

All mothers in the study were nulliparous and had relatively long labours. This mode of analgesia might be more useful in multiparas who, generally, have shorter labours. Although there were more maternal side-effects in the fentanyl group, these were mild or moderate. No serious side-effects were seen.

For the fetal well-being we did not find any harmful effects of fentanyl PCA, as no changes were detected in CTG recordings. This differs from a previous study by Rayburn $e t$ al. ${ }^{20}$ who reported a brief decrease in fetal heart rate variability after iv fentanyl in labour. All the newborns in this study were healthy and vigorous at birth. None of the babies needed naloxone. The
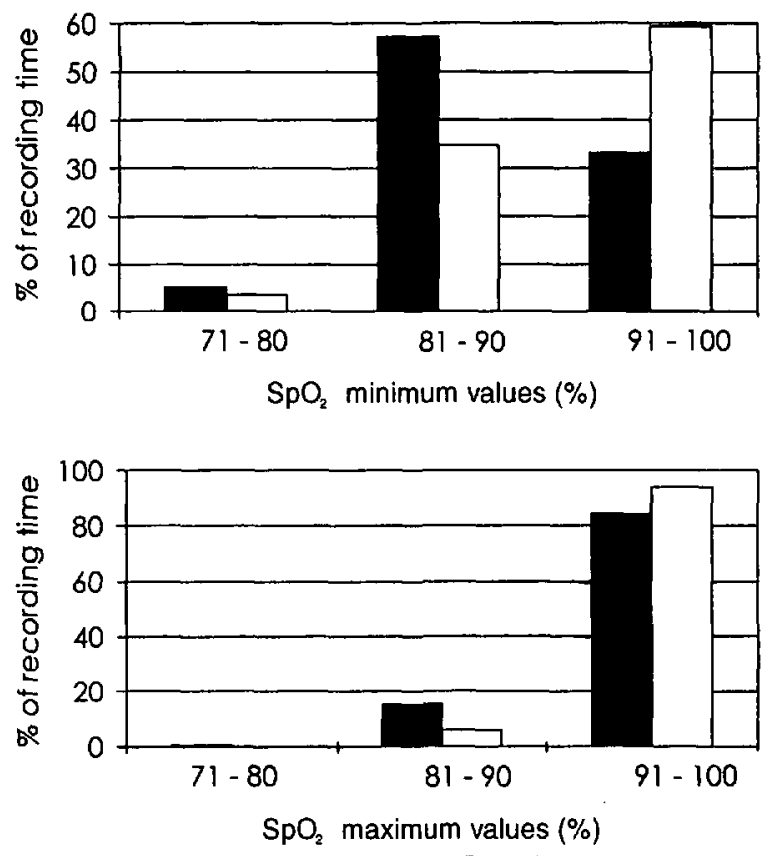

FIGURE 2 Minimum and maximum values of the neonatal arterial oxyhaemoglobin saturation $\left(\mathrm{SpO}_{2}\right)$, percentage of the recording time.

= fentanyl group, $\square$ = epidural group

$P<0.001$ in both minimum and maximum values.

APGAR scores and umbilical $\mathrm{pH}$ values were similar in both groups. Also, the neurological capacity scoring was identical between groups: no drug-related effects were seen. These variables did not show any harmful fetal or neonatal effects of iv fentanyl.

The umbilical cord fentanyl concentrations in this study were low or beyond the detection limit of the assay. This further explains the absence of any gross opioid-linked signs in the newborns. No correlation was found between fentanyl concentrations and status of the newborn. The total fentanyl dose did not correlate with the neonatal status either. The lack of correlation may be due to the greatly variable elimination capacity of fentanyl in the newborns. ${ }^{16,30}$ Also, the time between the last fentanyl bolus and delivery was quite long. Probably, the short-acting fentanyl had been largely eliminated from the fetus and umbilical cord before delivery.

When systemic opioids are used during labour, neonatal monitoring is important due to the potential side-effects of those drugs. The SCSB method was used in an attempt to detect sub-clinical drug-related effects. We had expected to see lower breathing frequency, less motor activity and more sleep in babies receiving fentanyl. The SCSB method was originally developed 
for adults, ${ }^{28}$ but it has proved to be useful for infant recordings. ${ }^{31-34}$ The SCSB method has also been used in pharmacological studies. ${ }^{35}$

The $12 \mathrm{hr}$ monitoring of newborns revealed some differences between the clinically similar babies. There were differences in the distribution of sleep stages, although these were not statistically significant. In the fentanyl group we found more active sleep than in the epidural group. Also, the fentanyl group babies had less awake periods and less quiet and intermediate sleep than controls. Opioids have previously shown to decrease quiet sleep and increase active sleep in human newborns. ${ }^{36,37}$

It is now accepted that newborns and, perhaps, fetuses feel pain. ${ }^{38,39}$ Fetal and neonatal pain and stress are said to be related to an increased amount of quiet sleep. ${ }^{40,41}$ Therefore, babies with less pain and stress during delivery may have less quiet sleep after birth. Also, fentanyl prevents the biochemical and endocrine stress responses to painful stimuli during surgical operations in newborn infants. ${ }^{42}$ Therefore, another hypothesis for the decreased amount of quiet sleep in the fentanyl group babies could be the diminished delivery stress and pain of the fetus and newborn baby.

With larger group sizes the differences in sleep stages may have become statistically significant. The clinical importance of sleep stage changes and whether those changes have any benefits or disadvantages for the newborn baby are unknown.

The $\mathrm{SpO}_{2}$, both minimum and maximum values, was lower in the fentanyl group of babies. The fentanyl neonates had more events of $\mathrm{SpO}_{2}<90 \%$, most of which were brief. Desaturation $<80 \%$ was rare in both groups. Although the newborns in our study were clinically healthy and naloxone was not needed, the differences in oxygenation are disturbing. Fortunately, desaturation is easy to detect with $\mathrm{SpO}_{2}$ monitors and easy to treat with naloxone. We were surprised that fentanyl did not to affect respiratory rate.

All the mothers in this study were healthy women with normal term pregnancies and all the newborns appeared to be healthy. Even in this normal material some desaturation occurred. If combined with other compromising factors $i v$ fentanyl might have more serious effects for the newborn. Therefore, when iv fentanyl is given to mothers in labour, the newborn oxygenation should be monitored after birth. Also, naloxone should be available if severe desaturation occurs.

We monitored the babies for $12 \mathrm{hr}$ and desaturation events occurred throughout this period. Therefore, in clinical practice, monitoring of the babies for several hours is recommended. Nowadays the pulse oximeters are small and movable, and there is no need to separate the babies and mothers due to $\mathrm{SpO}_{2}$ measurement.
The group sizes in this study were small, because we had anticipated that the differences between the groups would be more obvious. The study was time consuming, and we wanted to avoid unnecessarily separating babies from their mothers. A larger clinical study is needed to establish the safety of fentanyl dosing. Even with this group size, a $10 \%$ decrease in breathing frequency of the babies should have been distinguishable with a $90 \%$ power.

In conclusion, iv fentanyl can be used to provide labour analgesia in some situations, as an alternative to epidural blockade. With the doses used in this study fentanyl had an effect on maternal pain, but only some mothers was satisfied with the pain relief. For the fetus and baby there are potential risks but, in healthy babies we did not see any serious side-effects or need for naloxone. When fentanyl is used the fetus and newborn must be appropriately monitored. Also, naloxone and oxygen should be available if serious neonatal distress occurs. The SCSB method appeared applicable for the detection of neonatal drug effects, but in clinical practice the $\mathrm{SpO}_{2}$ monitoring is sufficient.

\section{Acknowledgments}

This work was supported by funds from Instrumentarium Research Foundation, Finland and funds from Turku University Hospital, Finland.

\section{References}

1 Lieberman E, Lang JM, Frigoletto $F J r$, Richardson $D K$, Ringer $S A$, Coben $A$. Epidural analgesia, intrapartum fever, and neonatal sepsis evaluation. Pediatrics 1997; 99: 415-9.

2 Rawal N, Allvin R. Management of obstetric pain in Europe - a 17-nation survey. Congress Abstract. Annual Congress of European Society of Anesthesiologists, London, 1996.

3 Ranta $P$, Jouppila $P$, Spalding $M$, Kangas-Saarela $T$, Hollmén A, Jouppila R. Parturients' assessment of water blocks, pethidine, nitrous oxide, paracervical and epidural blocks in labour. International Journal of Obstetric Anesthesia 1994; 3: 193-8.

4 Kariniemi V, Ämmälä $P$. Effects of intramuscular pethidine on fetal heart rate variability during labour. Br J Obstet Gynecol 1981; 88: 718-20.

5 Rosen MG, Scibetta J, Hochberg CJ. Human fetal electroencephalogram. III: pattern changes in presence of fetal heart rate alterations and after use of maternal medications. Obstet Gynecol 1970; 36: 132-40.

6 Boddy K, Dawes GS. Fetal breathing. Br Med Bull 1975; 31: 3-7.

7 Shnider SM, Moya F. Effects of meperidine on the newborn infant. Am J Obstet Gynecol 1964; 89: 1009-15. 
8 Taylor ES, von Fumetti $H H$, Essig $L L$, Goodman SN, Walker $L C$. The effects of demerol and trichloroethylene on arterial oxygen saturation in the newborn. Am J Obstet Gynecol 1955; 69: 348-51.

9 Roberts H, Kane KM, Percival N, Snow P, Please NW. Effects of some analgesic drugs used in childbirth with special reference to variation in respiratory minute volume of the newborn. Lancet 1957; 1: 128.

10 Koch $G$, Wandel $H$. The effect of pethidine on the postnatal adjustment of respiration and acid base balance. Acta Obstet Gynecol Scand 1968; 47: 27-37.

11 Burnard $E D$, Cross $K W$. Rectal temperature in the newborn after birth asphyxia. BMJ 1958; 2: 1197-9.

12 Brackbill $Y$, Kane J, Manniello RL, Abramson D. Obstetric meperidine usage and assessment of neonatal status. Anesthesiology 1974; 40: 116-20.

13 Olofsson Ch, Ekblom A, Ekman-Ordeberg G, Hjelm A, Irestedt $L$. Lack of analgesic effect of systemically administered morphine or pethidine on labour pain. Br J Obstet Gynecol 1996; 103: 968-72.

$14 \mathrm{McClain} D A, \mathrm{Hug} C \mathrm{C} \mathrm{Jr}$. Intravenous fentanyl kinetics. Clin Pharmacol Ther 1980; 28: 106-14.

15 Kubnert BR, Linn PL, Kubnert PM. Obstetric medication and neonatal behavior. Current controversies. Clin Perinatol 1985; 12: 423-40.

16 Koehntop DE, Rodman JH, Brundage DM, Hegland $M G$, Buckley JJ. Pharmacokinetics of fentanyl in neonates. Anesth Analg 1986; 65: 227-32.

17 Yaster $M$. The dose response of fentanyl in neonatal anesthesia. Anesthesiology 1987; 66: 433-5.

18 Jarvis AP, Arancibia CU. A case of difficult neonatal ventilation (Letter). Anesth Analg 1987; 66: 196.

19 Craft JB Jr, Coaldrake LA, Bolan JC, et al. Placental passage and uterine effects of fentanyl. Anesth Analg 1983; 62: 894-8.

20 Rayburn W, Rathke A, Leuschen MP, Chleborad J, Weidner $W$. Fentanyl citrate analgesia during labor. Am J Obstet Gynecol 1989; 161: 202-6.

21 Rayburn WF, Smith CV, Parriot JE, Woods RE. Randomized comparison of meperidine and fentanyl during labor. Obstet Gynecol 1989; 74: 604-6.

22 Kleiman SJ, Wiesel S, Tessler MJ. Patient-controlled analgesia (PCA) using fentanyl in a parturient with a platelet function abnormality. Can J Anaesth 1991; 38: 489-91.

23 Rosaeg OP, Kitts JB, Koren G, Byford LJ. Maternal and fetal effects of intravenous patientcontrolled fentanyl analgesia during labour in a thrombocytopenic parturient. Can J Anaesth 1992; 39: 277-81.

24 Graves DA, Foster TS, Batenhorst RL, Bennett RL, Baumann TJ. Patient-controlled analgesia. Ann Intern Med 1983; 99: 360-6.

25 Kanto J, Erkkola R, Mansikka M, Ä̈̈rimaa L. Segmental epidural analgesia - a modern method for safe and effec- tive management of labor pains. Biological Research Pregnancy 1983; 4: 172-6.

26 Dawes GS, Moulden M, Redman CWG. System 8000: computerized antenatal FHR analysis. J Perinat Med 1991; 19: 47-51.

27 Amiel-Tison C, Barrier G, Shnider SM, Levinson $G$, Hughes SC, Stefani SJ. A new neurologic and adaptive capacity scoring system for evaluating obstetric medications in full-term newborns. Anesthesiology 1982; 56: 340-50.

28 Alihanka J, Vaabtoranta $K$, Saarikivi J. A new method of long-term monitoring of the ballistocardiogram, heart rate, and respiration. Am J Physiol 1981; 240: 384-92.

29 Alibanka J. Basic principles for analysing and scoring Bio-matt (SCSB) recordings. Annales Universitatis Turkuensis 1987; 26: 1-129.

$30 \mathrm{Katz} R$, Kelly $H W$. Pharmacokinetics of continuous infusions of fentanyl in critically ill children. Crit Care Med 1993; 21: 995-1000.

31 Erkinjuntti $M$, Vaabtoranta $K$, Alibanka $J$, Kero $P$. Use of the SCSB method for monitoring of respiration, body movements and ballistocardiogram in infants. Early Hum Dev 1984: 9: 119-26.

32 Erkinjuntti $M$, Kero $P$, Halonen J-P, Mikola H, Sainio $K$. SCSB method compared to EEG-based polygraphy in sleep state scoring of newborn infants. Acta Paediatr Scand 1990; 79: 274-9.

33 Kirjavainen $T$, Cooper $D$, Polo $O$, Sullivan $C E$. Respiratory and body movements as indicators of sleep stage and wakefulness in infants and young children. J Sleep Res 1996; 5: 186-94.

34 Kirjavainen $T$, Cooper D, Polo O, Sullivan CE. The static-charge-sensitive bed in the monitoring of respiration during sleep in infants and young children. Acta Paediatr 1996; 85: 1146-52.

35 Seppälä $M$, Alibanka J, Himberg J-J, Kanto J, Rajala $T$, Sourander L. Midazolam and flunitrazepam: pharmacokinetics and effects on night time respiration and body movements in the elderly. Int J Clin Pharmacol Ther Toxicol 1993; 31: 170-6.

36 Dinges DF, Dapis $M M$, Glass $P$. Fetal exposure to narcotics: neonatal sleep as a measure of nervous system disturbance. Science 1980; 209: 619-21.

37 Pinto F, Torrioli MG, Casella G, Tempesta E, Fundarò C Sleep in babies born to chronically heroin addicted mothers. A follow up study. Drug Alcohol Depend 1988; $21: 43-7$.

38 Anand KJS, Hickey PR. Pain and its effects in the human neonate and fetus. N Engl J Med 1987;21: 1321-9.

39 de Lima J, Lloyd-Thomas AR, Howard RF, Sumner E, Quinn TM. Infant and neonatal pain: anaesthetists' perceptions and prescribing patterns. BMJ 1996; 313: 787. 
40 Emde RN, Harmon RJ, Metcalf D, Koenig KL, Wagonfeld $S$. Stress and neonatal sleep. Psychosom Med 1971; 33: 491-7.

41 Freudigman $K A$, Thoman $E B$. Infant sleep during the first postnatal day: an opportunity for assessment of vulnerability. Pediatrics 1993; 92: 373-9.

42 Anand KJS, Sippell WG, Aynsley-Green A. Randomised trial of fentanyl anaesthesia in preterm babies undergoing surgery: effects on the stress response. Lancet 1987; 1: 243-8. 